enzyme has two sites: the enzymatic site and the allosteric site. Fixation of the regulating metabolite on the allosteric site slightly changes the shape of the protein and thus abolishes the activity of the enzyme. In the case of repression and induction of protein synthesis, the repressor produced under the control of the regulator gene is now assumed to be a protein (the evidence in favour of its not being a protein was not very good, and in the case of a lysogenic system there is now evidence that the repressor is probably a protein). The repressor-protein is believed to possess two sites: one of them recognizes the operator and interacts with it, thus locking the operon; the other site can bind the inducer metabolite. When the inducer metabolite is bound, the repressor protein is slightly changed, it loses affinity for the operator and the operon unlocks; a repressor metabolite, on the contrary, increases the affinity of the repressor protein for the operator. This new hypothesis affords a simple model of action of the inducing or repressing metabolite and thus removes one of the greatest difficulties of the previous models of enzyme induction. It also introduces more unity since the regulator gene is now regarded as a structural gene which specifies the repressor protein. The last day of the colloquium was devoted to a completely different field, namely, information in neurophysiology. A. Fessard gave a fascinating course on the mechanisms of brain, the nature of the messages, how they are processed and stored. $\mathrm{He}$ first outlined the several levels of organization: wiring diagram of neurones, neurone populations, cellular organization, synapses, membranes, macromolecular structures. He described the activity of the nerve fibre as revealed by the action potentials, and discussed how modulation of the time sequence of successive signals carry information. Depolarization, hyperpolarization and other processes occurring in the dendrite, and the role of the trigger zone in transmitting the messages were described. Then came the spatial aspect of impulse reception in the brain, the interconnexions between neurones, the filtration of signals and the increase of con. trast. Great emphasis was laid on the fact that the signals arriving to the brain are not restricted to a small primary area, that they go to many other parts where signals from other types of excitations also arrive. The code in which a certain excitation is translated is assumed to be in terms of patterns.

Finally, the problem of memory was outlined. Fessard described striking experiments on short-term and longterm memory, insisted on the absence of localization of the stored information, and indicated present interpretations. When hearing this lecture after those on enzyme structure and regulation one was led inescapably to think of memory as a regulation process, and to imagine a model in terms of allosteric effects on some synaptic structure. The conclusion of Fessard's lecture was that many of the elaborate properties of the nervous system can be explained. by random connexion between neurones, regulated by external actions. A similar conclusion applies to the evolution of the highly organized structure of proteins and nucleic acids. The high information content of the genes, the 'antihasard' which is so obvious in the structure of a protein like hæmoglobin or a double-headed enzyme can have their origin in known random events corrected by the purely deterministic challenge of the external medium. Teleological features of living matter are thus. already accounted for in terms of causality.

The participants in this symposium are grateful to their French colleagues, especially Prof. E. Aubel, secretary of the organizing committee, and to the Délégation générale à la Recherche scientifique et technique which provided financial support. The Abbey of Royaumont, the gardens, the musical evenings, and supper by candlelight are delightful memories for those who were privileged to take part in this most successful colloquium.

\section{H. ChanTRENNE}

\title{
THE INTERNATIONAL ATOMIC ENERGY AGENCY
}

$\mathrm{A}^{\mathrm{N}}$ $\mathrm{N}$ outline of the programme for 1963 of the International Atomic Energy Agency is given in the October issue of the Agency's Bulletin $(4$, No. 4, 11; 1962). A total budget of $9,562,100$ dollars has been proposed, representing an increase of approximately 7.5 per cent on the budget for 1962. Estimated expenditure under the heading of the "Regular Budget", financed out of assessed contributions by member states of the Agency, amounts to $7,337,500$ dollars. The remainder of the total budget is assessed under the heading of the "Operational Budget" and is financed out of voluntary contributions by member States and other resources, such as funds made available under the United Nations Expanded Programme of Technical Asssistance.

The Agency's technical assistance programme is to be extended. During 1962 requests for assistance involving the services of 40 experts, and equipment worth nearly 230,000 dollars were approved. This was in addition to some 36 experts already serving during 1962 under previously sanctioned projects. During 1963 the need will arise for the services of some 90 field experts, in addition to those whose assignments continue from previous years. Requests for equipment are expected to exceed the value of 250,000 dollars.

The Agency's training programme includes the award of fellowships and research grants. The number of applications for fellowships has increased steadily, but there has not been a corresponding increase in the funds available for the purpose. Hence during 1963 more extensive use is to be made of cost-free fellowships made available by member States, but even then it is anticipated that not all deserving requests will be able to be met. For use in training on the spot the Agency provides two mobile laboratories. Approximately 750 trainees in the Far East, Latin America and Europe have used these laboratories in the past years, and it is expected that one of the laboratories will move to Africa late in 1962 or early in 1963 .

A number of conferences and symposia are planned for 1963. A panel of experts is to meet to discuss the Ageney's report on the results of an investigation into the cost of nuclear power in an integrated system and its comparison with the cost of conventional power production, and another group of experts will discuss the physics of heavywater lattices. Symposia are to be held on materials for reactor control, including their metallurgical and physical properties and their design and fabrication; on new nuclear materials technology, with special reference to the use of such materials in the fabrication of non-metallic fuel elements; on the use of radioisotopes and radiation sources for the control of plant pests; on the use of isotopes in hydrology; on the biological effects of neutron irradiation and on the effects of radiation on the endocrino system; and on radiological health and safety in the mining and milling of nuclear materials; and the Agency's Scientific Advisory Committee has recommended that a seminar be held on some aspect of nuclear, solid-stato or plasma physics.

Research contracts in tropical medicine are to be awarded with the view of promoting the application of established radioisotope techniques to the study of diseases affecting large groups of people in the less- 
developed countries in tropical regions. A review is to be made of the results of the Agency sponsored research on calcium-47, and work on the calibration and standardization of measurements of uptake of radioiodine by the thyroid gland is to continue. The distribution of calibrated radionuclide samples will be extended during 1963 and new calibration methods will be developed. Participation in the international intercomparison measurements of radionuclides organized by the International Bureau of Weights and Measures will continue. The comparative study of methods used in different laboratories for the chemical analysis of nuclear materials; the determination of trace elements in the marine environment; and in mass spectroscopy, the programme of the application of stable isotopes to analyses by the isotope dilution method, and the direct analysis by the mass spectrograph of trace elements in sea-water and nuclear materials, are some of the investigations to continue or be commenced during the year.

There are indications that during 1963 a number of nuclear facilities will be subject to Agency safeguards, and plans are being made to buy the essential minimum of portable equipment needed for the inspections. The general problems of emergency conditions in the event of a serious accident in nuclear installations are to be reviewed and the Agency's plans for the provision of international emergency assistance to member states are to be extended. Increased attention is to be directed to the development of techniques to deal with the disposal and management of radioactive waste, atmospheric pollution, and the transport and distribution of radioactive material. In this connexion, any necessary revision to the Agency's regulations for the aafe transport of radioactive materials will be considered.
S. WeIntroub

\section{FOREST RESEARCH}

\begin{abstract}
1HE report on forest research for the year ended March 1961* shows the wide range of work being carried out by the Forestry Commission Research Staff and for the Forestry Commission, with assistance by workers at universities and other institutions.

Much more attention is now being paid to the forest soil. Drainage is often a great problem. Wet soils may have a severe effect on tree roots by inhibiting growth and also by making the trees vulnerable to windblow. With the machines now available, the initial drainage system for a bare area may not be a very difficult task but a great deal more information is required on the depth drains should be on a given site and how far apart they should be spaced in order to provide reasonable conditions for afforestation purposes. The subsequent problems include the maintenance of the drains and, unfortunately, there is quite a lot of evidence in Britain of neglected drains. However, ways and means for ensuring the provision of good drainage in forest areas are being investigated. Nutritional work is also being undertaken. The analysis of foliar samples from fertilizer trials is providing data on nutrient deficiencies. Another series of experiments is attempting to elucidate the role of mites in the breakdown of forest litter.
\end{abstract}

For the first time a report on work study is included. The activities of the section dealing with this cover investigations on tools, equipment, machinery, piecework and other matters affecting production operations at all levels.

A prototype direct-reading calliper has been developed and trials of this instrument have demonstrated that enumeration work can be speeded up and so costs are reduced. As the measurements are transferred directly on to a tape by a punch system, errors in recording can * Forestry Commission. Report on Forest Research for the Year ended
March 1961. Pp. ix $+209+12$ plates. (London: H.M.S.O., 1962.) 14s. net. be avoided. Two plates show some details of this calliper but no details are given of its weight. At least two other types of self-recording callipers are in use in Scandinavia.

In the report of the New Zealand Forest Service's Forest Research Institute for $1961 \mathrm{f}$, mention is made of the new requirement that although officers out with the Research Division are still encouraged to conduct their own research projects, these must be approved by the Director of Research. This is a wise ruling. The individual is not thwarted, co-ordination is possible and one of the great drawbacks to individual research in forestry will be avoided, namely, the discontinuance of an experiment through the transfer of an officer to another territorial charge.

It is good to read that one of the planned developments is in physiology and the reason given is "because it is basic to an understanding of many problems in the fields of silviculture, forest-tree improvement and forest pathology". Another development is the appointment of a "silvicultural economics" team with the object of constructing financial yield tables for exotic species. This shows a realistic approach to land-use evaluation and will form a proper basis for the assessment of the relative merits of agriculture and forestry whenever such is required and it is expected to be more needed in the future. In addition, it is felt in New Zealand that a new approach is required in forest economics which, for so long, has been conditioned by European practice.

There is nothing perfunctory about the forest research described in this report. Indeed, the reader is convinced that forest research in New Zealand is well planned and vigorous, and that, in addition to trying to solve presentday problems, it is also forward-looking in a very commendable way.

C. J. TAYLOB $\dagger$ New Zealand Forest Service. Forest Research Institute, Rotorua.
Report for the year 1961. Pp. 75. (Wellington, N.Z.: Government Printer, 1962.)

\section{ASPERGILLUS FLAVUS AND GROUNDNUT TOXICITY}

$I^{\mathrm{N}}$ 1960, large numbers of young turkeys in Britain died (and, later, other domestic birds and farm animals were shown to be affected) for a reason that was at first unknown and was called 'turkey $\mathbf{X}$ disease'. This was later shown to be due to the presence of a toxic batch of groundnut meal in their 'feed'. As a result of this, a number of Government and other research laboratories studied this toxicity as a matter of urgency. Real progress became possible with the demonstra- tion that the toxin was not intrinsic to the groundnuts themselves but was the product of a mould (a strain of Aspergillus flavus) growing on them. This toxin-producing mould is widespread, and it was not surprising, therefore, that the toxin was identifiable on some samples of groundnuts or meal from all the main producing areas.

Because the problems posed overlapped the responsibilities of a number of Government departments, an 